\title{
Shimazuella kribbensis gen. nov., sp. nov., a mesophilic representative of the family Thermoactinomycetaceae
}

\author{
Correspondence \\ Chang-Jin Kim \\ changjin@kribb.re.kr
}

\author{
Dong-Jin Park, ${ }^{1} \dagger$ Syed G. Dastager, ${ }^{1} \dagger$ Jae-Chan Lee, ${ }^{1}$ Soo-Hwan Yeo, ${ }^{2}$ \\ Jung-Hoon Yoon ${ }^{1}$ and Chang-Jin Kim ${ }^{1}$
${ }^{1}$ Korea Research Institutes of Biosciences and Biotechnology, 52 Eoeun-dong, Yuseong gu, Daejeon 305-333, Republic of Korea Rural Development Administration, Suwon 411-853, Republic of Korea \\ ${ }^{2}$ Rural Resources Development Institute, National Institute of Agricultural Science and Technology,
}

\begin{abstract}
A mesophilic strain, designated $A 9500^{\top}$, was isolated from a soil sample collected from Sobaek Mountain, South Korea, and its taxonomic position was investigated by using a polyphasic approach. The novel strain grew well on different ISP media and no diffusible pigments were produced. The optimum temperature for growth was $32{ }^{\circ} \mathrm{C}$. The aerial mycelium was well developed, but not fragmented. The strain was Gram-positive, non-motile and formed endospores on vegetative and aerial hyphae with a spiny surface. Cell walls of strain $A 9500^{\top}$ contained meso-diaminopimelic acid as the diagnostic amino acid, but no characteristic sugars or other amino acids were found (chemotype-III). The major menaquinone was $\mathrm{MK}-9\left(\mathrm{H}_{4}\right)$ and the minor menaquinone was $\mathrm{MK}-10\left(\mathrm{H}_{4}\right)$ and they were detected at a ratio of $7: 3$. Phosphatidylethanolamine was the diagnostic phospholipid. The $\mathrm{G}+\mathrm{C}$ content of the genomic DNA was $39.4 \mathrm{~mol} \%$. The major fatty acids were anteiso- $\mathrm{C}_{15: 0}(43.34 \%)$, iso- $\mathrm{C}_{16: 0}(14.23 \%)$ and $\mathrm{C}_{16: 0}$ $(7.90 \%)$, a composition that differed from members of related genera of the family

Thermoactinomycetaceae. The novel strain formed a distinct clade in a phylogenetic tree based on $16 \mathrm{~S}$ rRNA gene sequences. On the basis of a range of phenotypic and genotypic data and on 16S rRNA gene sequence similarities (88.35-90.38\%), it is suggested that strain $\mathrm{A} 9500^{\top}$ represents a novel species in a new genus with the name Shimazuella kribbensis gen. nov., sp. nov. The type strain of the type species is $A 9500^{\top}\left(=\mathrm{KCTC} 9933^{\top}=\mathrm{DSM} 45090^{\top}\right)$.
\end{abstract}

The genus Thermoactinomyces (Tsilinsky, 1899) was the first described member of the family Thermoactinomycetaceae (Matsuo et al., 2006). Recently, based on $16 \mathrm{~S}$ rRNA gene sequence analysis, as well as chemotaxonomic and physiological characterization, the members of the genus Thermoactinomyces have been divided into six genera, Thermoactinomyces sensu stricto (Yoon et al., 2005), Laceyella (Yoon et al., 2005), Thermoflavimicrobium (Yoon et al., 2005), Seinonella (Yoon et al., 2005), Planifilum (Hatayama et al., 2005) and Mechercharimyces (Matsuo et al., 2006). At the time of writing, the reclassification of the family Thermoactinomycetaceae means that there are now the following recognized species: Thermoactinomyces candidus (Kurup et al., 1975; proposed as a later synonym of Thermoactinomyces vulgaris by Yoon et al. 2000); Thermoactinomyces vulgaris (Tsilinsky, 1899); Thermoactinomyces intermedius (Kurup et al., 1980);

†These authors contributed equally to this work.

The GenBank/EMBL/DDBJ accession number for the 16S rRNA gene sequence of strain $\mathrm{A} 9500^{\top}$ is $\mathrm{AB} 049939$.
Thermoactinomyces thalpophilus (Unsworth \& Cross, 1980; proposed as a later synonym of Thermoactinomyces sacchari by Yoon et al. 2000); Thermoflavimicrobium dichotomicus (Krasil'nikov \& Agre, 1964; Cross \& Goodfellow, 1973); Laceyella sacchari (Lacey, 1971; Yoon et al., 2005; basonym Thermoactinomyces sacchari); Laceyella putida (Lacey \& Cross, 1989; Yoon et al., 2005; basonym Thermoactinomyces putidus); Seinonella peptonophila (Nonomura \& Ohara, 1971; Yoon et al., 2005; basonym Thermoactinomyces peptonophilus); Planifilum fimeticola (Hatayama et al., 2005); Planifilum fulgidum (Hatayama et al., 2005); Mechercharimyces mesophilus (Matsuo et al., 2006) and Mechercharimyces asporophorigenens (Matsuo et al., 2006). These species are aerobic, Gram-positive and thermophilic, with the exception of two mesophilic species, Seinonella peptonophila and Mechercharimyces mesophilus. Here we describe another mesophilic member of the family Thermoactinomycetaceae.

Strain A $9500^{\mathrm{T}}$ was isolated and maintained on Bennett's agar (Atlas, 1993) medium for 2 weeks at $30{ }^{\circ} \mathrm{C}$. Other media used for cultural characteristics were inorganic 
salt-starch agar, yeast extract/malt extract agar, oatmeal agar, glycerol asparagine agar and tyrosine agar (Shirling \& Gottlieb, 1966). The morphological characteristics of 7 day cultures of strain A $9500^{\mathrm{T}}$ grown on Bennett's agar were observed by light microscopy (JEOL) and scanning electron microscopy (SEM 515; Philips). Morphological studies revealed that the new isolate shared the characteristics already described for the family Thermoactinomycetaceae, with white aerial mycelium and pale yellow substrate mycelium which was well developed. Substrate mycelium was branched, but not fragmented. Spores formed singly $(1.0-1.4 \times 0.7-0.9 \mu \mathrm{m})$ on aerial mycelium and were non-motile (Fig. 1a). Substrate hyphae were sessile and had extensively branched $(0.3-0.6 \mu \mathrm{m})$ sporophores with the structure and properties of bacterial endospores (Fig. 1b). The colours of the substrate and aerial mycelia and any soluble pigments were determined (Kelly, 1964). Strain A $9500^{\mathrm{T}}$ grew on all media tested. Good growth was observed on Bennett's agar and no diffusible pigments were produced on the media tested.

The temperature range for growth was $20-50{ }^{\circ} \mathrm{C}$, with the optimum temperature at $32{ }^{\circ} \mathrm{C}$. The $\mathrm{pH}$ and $\mathrm{NaCl}$ tolerance was examined as described by Tang et al. (2003). Other physiological features and carbon source utilization were observed on a basal medium used for cultivation of members of the genus Thermoactinomyces (Williams et al., 1989). Detailed physiological and biochemical characteristics of the novel isolate are given in Table 1 and in the species description.
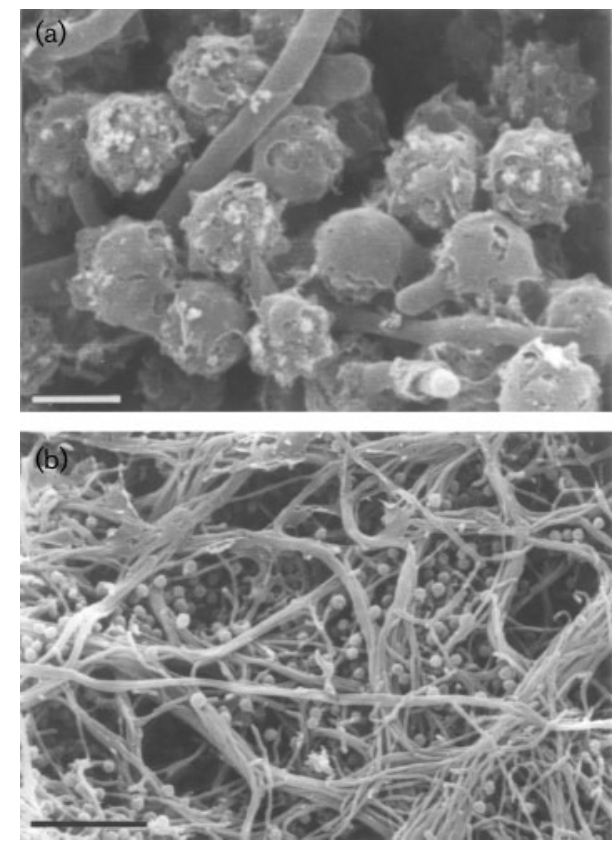

Fig. 1. Scanning electron micrographs of cells of Shimazuella kribbensis sp. nov. A $9500^{\top}$ grown on ISP medium 2 for 7 days at $32{ }^{\circ} \mathrm{C}$, showing aerial mycelium spores (a) and spiny spores on the substrate mycelium (b). Bars, $1 \mu \mathrm{m}$ (a) and $10 \mu \mathrm{m}$ (b).
The chemotaxonomic characteristics of strain A $9500^{\mathrm{T}}$ were determined using cells cultured in Bennett's medium at the exponential phase of growth. The composition of the amino acids and sugars in the cell-wall peptidoglycan was determined by the methods of Lechevalier \& Lechevalier (1980) and Schleifer \& Kandler (1972) using cellulose TLC plates. The menaquinone and cellular fatty acid profiles were determined as described by Collins et al. (1977) and were analysed by HPLC (Kroppenstedt, 1982). The cellwall peptidoglycan of the novel isolate contained mesodiaminopimelic acid (meso-DAP), glutamic acid and alanine, but no diagnostic sugars. Thus strain A $9500^{\mathrm{T}}$ had an unusual type III cell wall (Lechevalier \& Lechevalier, 1970). This result was consistent with that obtained previously for other members of the family Thermoactinomycetaceae. The diagnostic phospholipid was phosphatidylethanolamine. However, the predominant menaquinones were MK-9 $\left(\mathrm{H}_{4}\right)$ and $\mathrm{MK}-10\left(\mathrm{H}_{4}\right)$ in a ratio of $7: 3$. For the above analysis, the organism was cultivated on Bennett's broth for 3 days at $32{ }^{\circ} \mathrm{C}$ and harvested by centrifugation at 3000 r.p.m. for 20 min. Cellular fatty acid analysis was performed as described by Sasser (1990) using the Microbial Identification System (MIDI). The fatty acid profile of strain A $9500^{\mathrm{T}}$ was mainly composed of anteiso$\mathrm{C}_{15: 0}(43.34 \%)$, iso- $\mathrm{C}_{16: 0}(14.23 \%), \mathrm{C}_{16: 0}(7.90 \%)$, iso$\mathrm{C}_{15: 0}(7.40 \%)$, anteiso- $\mathrm{C}_{17: 0}(7.17 \%)$, iso- $\mathrm{C}_{14: 0}(6.14 \%)$, $\mathrm{C}_{15: 0}(4.01 \%)$ and anteiso- $\mathrm{C}_{16: 0}(3.76)$. The G+C DNA content of strain A $9500^{\mathrm{T}}$ was determined by using the HPLC method of Mesbah et al. (1989) and was $39.4 \mathrm{~mol} \%$.

Extraction and amplification of genomic DNA for $16 \mathrm{~S}$ rRNA gene sequence analysis was carried out as described by Cui et al. (2001). The 16S rRNA gene fragment was amplified by using universal primers corresponding to positions 8-27 for the forward primer and 1492-1510 for the reverse primer (Escherichia coli numbering system; Weisburg et al., 1991). Based on 1459 bp long 16S rRNA gene sequences, phylogenetically related bacteria were aligned by using a BLAST search (Altschul et al., 1990) against the GenBank database. Multiple alignments with sequences of related taxa of the family Thermoactinomycetaceae were implemented by using CLUSTAL_X (Thompson et al., 1997). The 16S rRNA gene sequence similarity values were calculated by pairwise comparison (Kimura, 1980). Phylogenetic trees (Fig. 2) were constructed based on different tree-making algorithms, namely the neighbour-joining (Saitou \& Nei, 1987), least squares (Fitch \& Margoliash, 1967), maximum-likelihood (Felsenstein, 1993) and maximum-parsimony (Fitch, 1971) methods. A neighbour-joining tree was reconstructed from evolutionary distances calculated using the Jukes-Cantor coefficient (Jukes \& Cantor, 1969). The topology of the phylogenetic tree was evaluated by the bootstrap resampling method of Felsenstein (1985) with 1000 replicates.

In the phylogenetic dendrogram, strain A $9500^{\mathrm{T}}$ formed a stable clade (supported by a $63 \%$ bootstrap value, see Fig. 2) with Laceyella putida KCTC $3666^{\mathrm{T}}$. The highest $16 \mathrm{~S}$ 


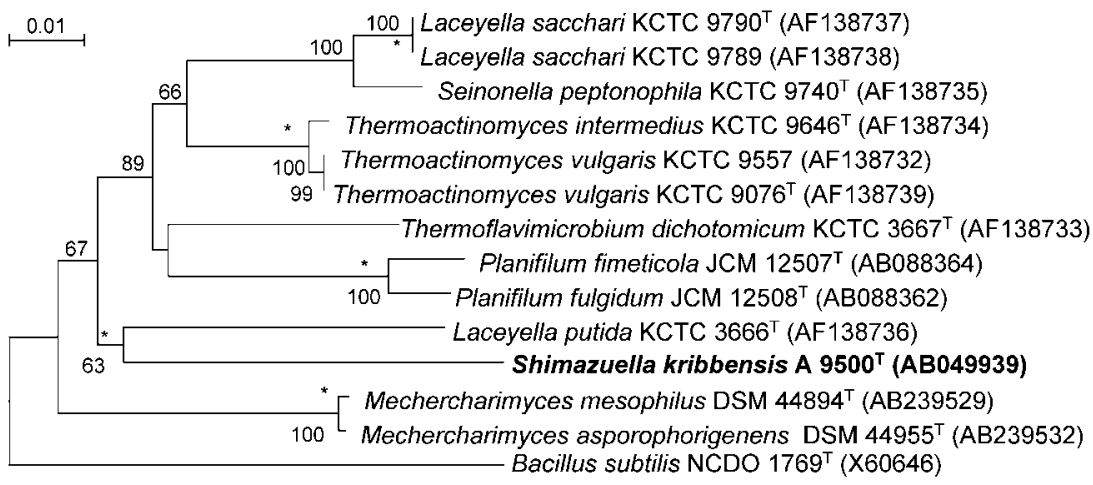

Fig. 2. Phylogenetic dendrogram based on 16S rRNA gene sequence analysis, reconstructed from evolutionary distances by using the neighbour-joining method, showing the position of strain $\mathrm{A} 9500^{\top}$ within the family Thermoactinomycetaceae. Asterisks indicate branches that were recovered using leastsquares (Fitch \& Margoliash, 1967), maximumlikelihood (Felsenstein, 1993) and maximumparsimony (Fitch, 1971) algorithms. Bootstrap values $(>50 \%)$ based on 1000 replications are shown at the nodes. Bar, 0.01 substitutions per nucleotide position. Bacillus subtilis NCDO $1769^{\top}$ was used as the outgroup.
rRNA gene similarity values found between strain A $9500^{\mathrm{T}}$ and other genera of the family Thermoactinomycetaceae were with Thermoactinomyces vulgaris KCTC 9557 ( $90.38 \%$ gene sequence similarity), Thermoflavimicrobium dichotomicum KCTC $3667^{\mathrm{T}}(90.22 \%)$, Laceyella sacchari KCTC $9790^{\mathrm{T}}$ (90.04\%), Thermoactinomyces intermedius KCTC $9646^{\mathrm{T}}(89.98 \%)$, Laceyella putida KCTC $3666^{\mathrm{T}}$ (89.67\%), Mechercharimyces asporophorigenens DSM $44955^{\mathrm{T}} \quad(89.50 \%)$, Mechercharimyces mesophilus DSM $44894^{\mathrm{T}}(89.41 \%)$, Seinonella peptonophila KCTC $9740^{\mathrm{T}}$
(89.41\%), Planifilum fimeticola JCM $12507^{\mathrm{T}}(88.43 \%)$ and Planifilum fulgidum JCM $12508^{\mathrm{T}}$ (88.35\%). The length of sequence compared was $1459 \mathrm{bp}$.

It is evident from the gene sequence similarity values, the phylogenetic tree (Fig. 2) and the phenotypic properties (Table 1) that strain A $9500^{\mathrm{T}}$ can be clearly distinguished from other genera of the family Thermoactinomycetaceae. Examination of the growth temperature, DNA G + C contents, menaquinone composition, cellular fatty acid

Table 1. Phenotypic differentiation of strain $A 9500^{\top}$ and related genera of the family Thermoactinomycetaceae

Taxa: 1, strain A 9500T ; 2, Laceyella; 3, Mechercharimyces; 4, Planifilum; 5, Seinonella; 6, Thermoactinomyces; 7, Thermoflavimicrobium. +, Positive reaction; -, negative reaction; +/-, variable reaction; No, not observed; ND, no data. Data from this study, Yoon et al. (2005), Hatayama et al. (2005) and Matsuo et al. (2006).

\begin{tabular}{|c|c|c|c|c|c|c|c|}
\hline Characteristic & 1 & 2 & 3 & 4 & 5 & 6 & 7 \\
\hline Colour of aerial mycelia & White & White & White & NO & White & White & Yellow \\
\hline $\begin{array}{l}\text { Growth on } 25 \mu \mathrm{g} \\
\text { novobiocin } \mathrm{ml}^{-1}\end{array}$ & + & + & + & ND & - & + & + \\
\hline \multicolumn{8}{|l|}{ Degradation of: } \\
\hline Casein & + & + & + & + & - & + & + \\
\hline Gelatin & - & + & + & ND & - & + & + \\
\hline Starch & + & - & + & + & - & + & + \\
\hline Hypoxanthine & - & - & - & - & - & - & + \\
\hline Xanthine & - & - & - & - & - & - & + \\
\hline L-Tyrosine & - & $+1-$ & - & - & - & - & - \\
\hline $\begin{array}{l}\text { Optimum temperature } \\
\text { for growth }\left({ }^{\circ} \mathrm{C}\right)\end{array}$ & 32 & $48-55$ & 30 & $55-63$ & 35 & $50-55$ & 55 \\
\hline $\begin{array}{l}\text { Predominant } \\
\text { menaquinone }\end{array}$ & MK-9 & MK-9 & MK-9 & MK-7 & MK-7 & MK-7 & MK-7 \\
\hline $\begin{array}{l}\text { Other menaquinone(s) } \\
>10 \% \text { peak area ratio }\end{array}$ & MK-10 & $\begin{array}{l}\text { MK-7, MK-8 } \\
\text { or MK-10 }\end{array}$ & MK-8 & $\mathrm{ND}^{*}$ & $\begin{array}{c}\text { MK-8, MK-9, } \\
\text { MK-10 }\end{array}$ & MK- 8 or MK-9 & $\mathrm{ND}^{*}$ \\
\hline Major fatty acids & $\begin{array}{l}\text { iso- } \mathrm{C}_{15: 0} \\
\text { anteiso- } \mathrm{C}_{15: 0} \\
\text { iso- } \mathrm{C}_{16: 0}, \mathrm{C}_{16: 0} \\
\text { anteiso- } \mathrm{C}_{17: 0}\end{array}$ & $\begin{array}{l}\text { iso- } \mathrm{C}_{15: 0} \\
\text { anteiso- } \mathrm{C}_{15: 0}\end{array}$ & $\begin{array}{l}\text { iso- } \mathrm{C}_{15: 0} \\
\text { iso- } \mathrm{C}_{17: 0} \omega 11 c\end{array}$ & $\begin{array}{l}\text { iso- } \mathrm{C}_{17: 0}, \\
\text { anteiso- } \mathrm{C}_{17: 0}, \\
\text { (iso- } \mathrm{C}_{15: 0} \text { or } \\
\mathrm{C}_{16: 0} \text { ) }\end{array}$ & $\begin{array}{l}\text { iso- } \mathrm{C}_{14: 0} \\
\text { anteiso- } \mathrm{C}_{15: 0}, \\
\text { iso- } \mathrm{C}_{16: 0}\end{array}$ & $\begin{array}{l}\text { iso- } \mathrm{C}_{15: 0} \\
\text { iso- } \mathrm{C}_{17: 0} \\
\text { anteiso- } \mathrm{C}_{15: 0}\end{array}$ & $\begin{array}{l}\text { iso- } \mathrm{C}_{15: 0}, \\
\text { anteiso- } \mathrm{C}_{15: 0}, \\
\text { iso- } \mathrm{C}_{16: 0}\end{array}$ \\
\hline $\begin{array}{l}\text { DNA G }+C \text { content } \\
(\mathrm{mol} \%)\end{array}$ & 39.4 & $48.0-49.0$ & 45.0 & $58.7-60.3$ & 40.0 & 48.0 & 43.0 \\
\hline
\end{tabular}

${ }^{\star}$ MK-8 detected at a trace level of $1.9 \%$ peak area ratio (Hatayama et al., 2005). 
content and the ability to degrade gelatin reveals that strain A $9500^{\mathrm{T}}$ does not belong to the genera Thermoactinomyces sensu stricto, Laceyella, Thermoflavimicrobium, Seinonella, Planifilum or Mechercharimyces. On the basis of the results presented in this study, strain A $9500^{\mathrm{T}}$ has been assigned to a novel genus in the family Thermoactinomycetaceae, for which the name Shimazuella kribbensis gen. nov., sp. nov. is proposed.

\section{Description of Shimazuella gen. nov.}

Shimazuella (Shi.ma.zu.el'la. N.L. fem. n. Shimazuella named after Akira Shimazu, a Japanese microbiologist from Tokyo University, who has contributed to the field of prokaryotic taxonomy).

Cells are Gram-positive, aerobic and mesophilic. Aerial mycelium is abundant and white and is not fragmented. Forms well-developed, branched and septate substrate mycelia on Bennett's agar and yeast extract-malt extract (ISP 2). Soluble pigments are not produced. The cell-wall peptidoglycan contains meso-diaminopimelic acid, glutamic acid and alanine, but no characteristic sugars. Endospores are produced singly along mycelia. The major menaquinone is MK-9 and is found at a ratio of 7:3 with MK-10. Major fatty acids are anteiso- $C_{15: 0}$, iso- $C_{16: 0}$, $\mathrm{C}_{16: 0}$, iso- $\mathrm{C}_{15: 0}$ and anteiso- $\mathrm{C}_{17: 0}$. The $\mathrm{G}+\mathrm{C}$ content is $39.4 \mathrm{~mol} \%$. The type species is Shimazuella kribbensis.

\section{Description of Shimazuella kribbensis sp. nov.}

Shimazuella kribbensis (krib.ben'sis. N.L. fem. adj. kribbensis pertaining to KRIBB, an arbitrary adjective formed from the acronym of the Korea Research Institute of Bioscience and Biotechnology, KRIBB, where the taxonomic studies on this new genus and novel species were performed).

In addition to the genus description, exhibits the following characteristics. Colonies are fast-growing, ridged with white mycelia and a feathery margin on Bennett's agar at $28{ }^{\circ} \mathrm{C}$. Growth occurs between 20 and $37^{\circ} \mathrm{C}$, with optimum growth at $32{ }^{\circ} \mathrm{C}$. Forms endospores singly on unbranched sporophores. Casein and starch are degraded, but not gelatin, hypoxanthine, xanthine or L-tyrosine. No pigments are observed on all media tested. Growth occurs in the presence of $25 \mu \mathrm{g}$ novobiocin $\mathrm{ml}^{-1}$. Major cellular fatty acids are anteiso- $\mathrm{C}_{15: 0}$, iso- $\mathrm{C}_{16: 0}, \mathrm{C}_{16: 0}$, iso- $\mathrm{C}_{15: 0}$ and anteiso- $\mathrm{C}_{17: 0}$. The DNA G $+\mathrm{C}$ content of the type strain is $39.4 \mathrm{~mol} \%$.

The type strain, A $9500^{\mathrm{T}}\left(=\mathrm{KCTC} 9933^{\mathrm{T}}=\mathrm{DSM} 45090^{\mathrm{T}}\right)$, was isolated from a soil sample collected from Sobaek mountain, Republic of South Korea.

\section{Acknowledgements}

We wish to acknowledge the great contribution of the late Dr Akira Shimazu to this study. This work was supported by the 21C Frontier Microbial Genomics and Application Centre program Korean Ministry of Science \& Technology (MOST) and Korea Foundation for International Cooperation of Science \& Technology (KICOS) through a grant provided by MOST in Global Partnership Program (No. M60602000001-06E0200-00100), Republic of Korea.

\section{References}

Altschul, S. F., Gish, W., Miller, W., Myers, E. W. \& Lipman, D. J. (1990). Basic local alignment search tool. J Mol Biol 215, 403-410.

Atlas, R. M. (1993). Handbook of Microbiological Media, pp. 126-127. Edited by L. C. Parks. Florida: CRC Press.

Collins, M. D., Pirouz, T., Goodfellow, M. \& Minnikin, D. E. (1977). Distribution of menaquinones in actinomycetes and corynebacteria. J Gen Microbiol 100, 221-230.

Cross, T. \& Goodfellow, M. (1973). Taxonomy and classification of the actinomycetes. In Actinomycetales: Characteristics and Practical Importance, pp. 11-112. Edited by G. Sykes \& F. A. Skinner. London: Academic Press.

Cui, X. L., Mao, P. H., Zeng, M., Li, W. J., Zhang, L. P., Xu, L. H. \& Jiang, C. L. (2001). Streptomonospora salina gen. nov., sp. nov., a new member of the family Nocardiopsaceae. Int J Syst Evol Microbiol 51, 357-363.

Felsenstein, J. (1985). Confidence limits on phylogenies: an approach using the bootstrap. Evolution 39, 783-791.

Felsenstein, J. (1993). PHYLIP (phylogenetic inference package), version 3.5c. Distributed by the author. Department of Genome Sciences, University of Washington, Seattle, USA.

Fitch, W. M. (1971). Toward defining the course of evolution: minimum change for a specific tree topology. Syst Zool 20, 406-416.

Fitch, W. M. \& Margoliash, E. (1967). Construction of phylogenetic trees; a method based on mutation distances as estimated from cytochrome $c$ sequences is of general applicability. Science 155, 279-284.

Hatayama, K., Shoun, H., Ueda, Y. \& Nakamura, A. (2005). Planifilum fimeticola gen. nov., sp. nov. and Planifilum fulgidum sp. nov., novel members of the family 'Thermoactinomycetaceae' isolated from compost. Int J Syst Evol Microbiol 55, 2101-2104.

Jukes, T. H. \& Cantor, C. R. (1969). Evolution of protein molecules. In Mammalian Protein Metabolism, vol. 3, pp. 21-132. Edited by H. N. Munro. New York: Academic Press.

Kelly, K. L. (1964). Inter-Society Color Council National Bureau of Standards Color-Name Charts Illustrated with Centroid Colors. Washington, DC: US Government Printing Office.

Kimura, M. (1980). A simple method for estimating evolutionary rates of base substitutions through comparative studies of nucleotide sequences. J Mol Evol 16, 111-120.

Krasil'nikov, N. A. \& Agre, N. S. (1964). A new actinomycete genus Actinobifida n. gen. yellow group - Actinobifida dichotomica n. sp. Mikrobiologiya 33, 935-943 (in Russian).

Kroppenstedt, R. M. (1982). Separation of bacterial menaquinones by HPLC using reverse phase (RP 18) and a silver loaded ion exchanger. J Liq Chromatogr 5, 2359-2387.

Kurup, V. P., Barboriak, J. J., Fink, J. N. \& Lechevalier, M. P. (1975). Thermoactinomyces candidus, a new species of thermophilic actinomycetes. Int J Syst Bacteriol 25, 150-154.

Kurup, V. P., Hollick, G. E. \& Pagan, E. F. (1980). Thermoactinomyces intermedius, a new species of amylase negative thermophilic actinomycetes. Science - Ciencia Bol Cien Sur 7, 104-108.

Lacey, J. (1971). Thermoactinomyces sacchari sp. nov., a thermophilic actinomycete causing bagassosis. J Gen Microbiol 66, 327-338.

Lacey, J. \& Cross, T. (1989). Genus Thermoactinomyces Tsiklinsky $1899,501^{\mathrm{AL}}$. In Bergey's Manual of Systematic Bacteriology, vol. 4, 
pp. 2574-2585. Edited by S. T. Williams, M. E. Sharpe \& J. G. Holt. Baltimore: Williams \& Wilkins.

Lechevalier, M. P. \& Lechevalier, H. A. (1970). A critical evaluation of the genera of aerobic actinomycetes. In The Actinomycetales, pp. 393405. Edited by H. Prauser. Jena: Gustav Fischer.

Lechevalier, M. P. \& Lechevalier, H. A. (1980). The chemotaxonomy of actinomycetes. In Actinomycete Taxonomy, pp. 227-291. Edited by X. Dietz \& Y. Thayer. Arlington, VA: Society for Industrial Microbiology.

Matsuo, Y., Katsuta, A., Matsuda, S., Shizuri, Y., Yokota, A. \& Kasai, H. (2006). Mechercharimyces mesophilus gen. nov., sp. nov. and Mechercharimyces asporophorigenens sp. nov., antitumour substanceproducing marine bacteria, and description of Thermoactinomycetaceae fam. nov. Int J Syst Evol Microbiol 56, 2837-2842.

Mesbah, M., Premachandran, U. \& Whitman, W. B. (1989). Precise measurement of the $\mathrm{G}+\mathrm{C}$ content of deoxyribonucleic acid by highperformance liquid chromatography. Int J Syst Bacteriol 39, 159-167.

Nonomura, H. \& Ohara, Y. (1971). Distribution of actinomycetes in soil. X. New genus and species of monosporic actinomycetes in soil. J Ferment Technol 49, 895-903.

Saitou, N. \& Nei, M. (1987). The neighbor-joining method: a new method for reconstructing phylogenetic trees. Mol Biol Evol 4, 406-425.

Sasser, M. (1990). Identification of bacteria by gas chromatography of cellular fatty acids. USFCC Newsl 20, 16.

Schleifer, K. H. \& Kandler, O. (1972). Peptidoglycan types of bacterial cell walls and their taxonomic implications. Bacteriol Rev 36, 407-477.

Shirling, E. B. \& Gottlieb, D. (1966). Methods for characterization of Streptomyces species. Int J Syst Bacteriol 16, 313-340.
Tang, S. K., Li, W.-J., Dong, W., Zhang, Y.-G., Xu, L.-H. \& Jiang, C.-L. (2003). Studies of the biological characteristics of some halophilic and halotolerant actinomycetes isolated from saline and alkaline soils. Actinomycetologica 17, 6-10.

Thompson, J. D., Gibson, T. J., Plewniak, F., Jeanmougin, F. \& Higgins, D. G. (1997). The CLUSTAL_X windows interface: flexible strategies for multiple sequence alignment aided by quality analysis tools. Nucleic Acids Res 25, 4876-4882.

Tsilinsky, P. (1899). On the thermophilic moulds. Ann Inst Pasteur. 13, 500-505 (in French).

Unsworth, B. A. \& Cross, T. (1980). Thermophilic actinomycetes implicated in farmer's lung: numerical taxonomy of Thermoactinomyces species. In Microbiological Classification and Identification, pp. 389-390. Edited by M. Goodfellow \& R. G. Broad. London: Academic Press.

Weisburg, W. G., Barns, S. M., Pelletier, D. A. \& Lane, D. J. (1991). 16 S ribosomal DNA amplification for phylogenetic study. J Bacteriol 173, 697-703.

Williams, S. T., Goodfellow, M. \& Alderson, G. (1989). Genus Streptomyces Waksman and Henrici 1943, 339 ${ }^{\mathrm{AL}}$. In Bergey's Manual of Systematic Bacteriology, vol. 4, pp. 2452-2492. Edited by S. T. Williams, M. E. Sharpe \& J. G. Holt. Baltimore: Williams \& Wilkins.

Yoon, J.-H. \& Park, Y.-H. (2000). Phylogenetic analysis of the genus Thermoactinomyces based on 16S rDNA sequences. Int J Syst Evol Microbiol 50, 1081-1086.

Yoon, J.-H., Kim, I.-G., Shin, Y.-K. \& Park, Y.-H. (2005). Proposal of the genus Thermoactinomyces sensu stricto and three new genera, Laceyella, Thermoflavimicrobium and Seinonella, on the basis of phenotypic, phylogenetic and chemotaxonomic analyses. Int J Syst Evol Microbiol 55, 395-400. 